\title{
Leaf water status and stem xylem flux in relation to soil drought in five temperate broad-leaved tree species with contrasting water use strategies
}

\author{
Paul Köcher, Tobias GEBAUER, Viviana HoRnA*, Christoph LEUSCHNER \\ Department of Plant Ecology, Albrecht-von-Haller-Institute for Plant Sciences, University of Göttingen, Untere Karspüle 2, \\ 37073 Göttingen, Germany
}

(Received 9 May 2008; accepted 29 Octobre 2008)

Keywords:

leaf conductance /

leaf water potential /

drought sensitivity /

mixed forest /

xylem sap flux

Mots-clés :

conductance foliaire /

potentiel hydrique foliaire /

sensibilité à la sécheresse /

forêt mixte /

flux de sève xylèmique

\begin{abstract}
- Five temperate broad-leaved tree species were compared with respect to their water consumption strategies under ample and restricted water supply. We measured synchronously leaf conductance $\left(g_{\mathrm{L}}\right)$ in the sun canopy, xylem sap flux $\left(J_{\mathrm{s}}\right)$ and leaf water potential (predawn, $\Psi_{\mathrm{pd}}$ and noon, $\left.\Psi_{\text {noon }}\right)$ in adult trees in a mixed stand and related them to the fluctuations in vapor pressure deficit $(D)$ and soil moisture.

- Maximum $g_{\mathrm{L}}$ was particularly high in F. excelsior, C. betulus and T. cordata and revealed a higher $D$ sensitivity. $\Psi_{\text {pd }}$ remained constantly high in A. pseudoplatanus, C. betulus and F. excelsior, but decreased in $T$. cordata and $F$. sylvatica with decreasing soil moisture.

- $J_{\text {sd }}$ decreased linearly with decreasing soil matrix potential in all species except for $F$. excelsior. Apparent hydraulic conductance in the soil-to-leaf flow path $\left(L_{\mathrm{c}}\right)$ was higher in A. pseudoplatanus than in the other species.

- F. sylvatica maintained a low maximum $g_{\mathrm{L}}$ and reduced $J_{\mathrm{sd}}$ markedly upon drought, but faced severe decreases in $\Psi_{\text {pd }}$ and $\Psi_{\text {noon }} . F$. excelsior represents an opposite strategy with high maximum $g_{\mathrm{L}}$ and stable $\Psi_{\mathrm{pd}}$.

- The species drought sensitivity increases in the sequence $F$. excelsior $<$. betulus $<T$. cordata $<$ A. pseudoplatanus $<$ F. sylvatica.
\end{abstract}

Résumé - Statut hydrique des feuilles et flux xylèmique dans le tronc en relation avec la sécheresse du sol pour cinq espèces d'arbres feuillus tempérés à stratégies de consommation d'eau différentes.

- Les stratégies de consommation d'eau de cinq espèces d'arbres feuillus tempérés ont été comparées sous approvisionnement en eau suffisant ou limité. De façon synchrone nous avons mesuré la conductance hydraulique des feuilles $\left(g_{\mathrm{L}}\right)$ dans la partie du couvert exposée au soleil, le flux de sève xylémique $\left(J_{\mathrm{s}}\right)$ et le potentiel hydrique foliaire (potentiel de base $\left(\Psi_{\mathrm{pd}}\right)$ et potentiel minimum $\left(\Psi_{\text {noon }}\right)$ ) d'arbres adultes en peuplement mixte et nous les avons reliés aux fluctuations du déficit de pression de vapeur $(D)$ et à l'humidité du sol.

- $g_{\mathrm{L}}$ maximum était particulièrement élevée chez $F$. excelsior, $C$. betulus et $T$. cordata et a révélé une plus grande sensibilité à D. $\Psi_{\text {pd }}$ est resté constamment élevé chez A. pseudoplatanus, C. betulus et F. excelsior, mais a diminué chez T. cordata et $F$. sylvatica lorsque l'humidité du sol diminuait.

- $J_{\text {sd }}$ a diminué linéairement avec le potentiel matriciel du sol pour toutes les espèces excepté $F$. excelsior. La conductivité hydraulique apparente du trajet sol-feuille $\left(L_{\mathrm{c}}\right)$ était plus élevée chez A. pseudoplatanus que dans les autres espèces.

- F. sylvatica a maintenu une faible $g_{\mathrm{L}}$ maximum et a réduit sensiblement $J_{\mathrm{sd}}$ face à la sécheresse, mais a connu de graves diminutions de $\Psi_{\text {pd }}$ et $\Psi_{\text {noon }}$. F. excelsior présentait une stratégie opposée avec une $g_{\mathrm{L}}$ maximum élevée et un $\Psi_{\mathrm{pd}}$ stable.

- La sensibilité des espèces à la sécheresse augmente selon la séquence $F$. excelsior $<$ C. betulus $<$ T. cordata $<$ A. pseudoplatanus $<F$. sylvatica.

\footnotetext{
* Corresponding author: vhorna@gwdg.de
} 


\section{INTRODUCTION}

As a consequence of global warming, an increase in the frequency and magnitude of summer droughts is predicted for Central Europe (Bréda et al., 2006; Meehl and Tebaldi, 2004; Schär et al., 2004). An expected rise in air temperature in temperate regions would increase the evaporative demand and should decrease available soil water relative to current conditions. The consequences of these changes for European temperate tree species and forests are still not sufficiently understood (Bovard et al., 2005).

Transpiration of co-existing tree species often varies greatly due to species-specific responses to variation in microclimatic and edaphic parameters (Granier et al., 1996; Oren et al., 2001; Pataki and Oren, 2003; Pataki et al., 2000). How tree species cope with a drier climate will depend on the species' capability to ensure water uptake under decreasing soil humidity. Tree species confronted with water stress will incur in structural or physiological adjustment in order to maintain the integrity of the hydraulic system and to enable carbon assimilation despite substantial water losses and a marked deterioration of plant water status (Bréda et al., 2006). Short term dynamic adaptation of trees to drought is achieved reducing transpiration via stomatal closure or reducing leaf water potential through active osmotic adjustment (Sperry, 2000). Long-term plastic responses to drought include regulation strategies like growing a deep rooting system, reducing leaf area or developing stems with high hydraulic conductivity and low cavitation risk (Sperry et al., 2002). Typically, trees combine elements of both strategies, but differ considerably in terms of stomatal regulation, hydraulic properties and growth sensitivity to drought. These traits may be crucial when temperate forests are exposed to increased summer drought, favouring species that are better adapted to avoid and/or tolerate water shortage and possibly inducing alterations in tree species composition.

In this study, we investigated leaf and whole tree water use and short-term regulation mechanisms in five cooccurring tree species growing in a species-rich temperate broad-leaved forest in Central Germany. Sycamore (Acer pseudoplatanus L.), European beech (Fagus sylvatica L.), European ash (Fraxinus excelsior L.), hornbeam (Carpinus betulus L.) and little-leaf linden (Tilia cordata Mill.) represent species with a contrasting distribution range in Europe and, thus, putatively differing in drought avoidance and tolerance strategies (Marigo et al., 2000; Bolte et al., 2007; Ellenberg and Leuschner, 2009). Except for beech, data on the drought response of the important Central European tree species is scarce (Aranda et al., 2005; Bréda et al., 2006; Cochard et al., 1996; Leuzinger et al., 2005; Magnani and Borguetti, 1995; Marek et al., 1989; Nardini and Salleo, 2000).

This study was conducted on adult trees growing under similar soil moisture and microclimate conditions. We used a canopy lifter which allowed access to the upper sun crown of two different trees of each of the five species listed above. By synchronously measuring leaf conductance for water vapour, apparent hydraulic conductance in the root and stem flow path, and leaf water potential in relation to atmospheric and soil water status, we aimed at a characterization of the five tree species' water consumption strategies under conditions of ample and limited soil water supply. Study objectives were (i) to compare the five tree species with respect to the $D$ sensitivity of leaf conductance, (ii) to quantify the influence of $D$ and soil matrix potential on xylem sap flux and leaf conductance, and (iii) to analyze the response of leaf water potential in these five species to decreasing soil matrix potential. These investigations in adult trees should help to improve our understanding of how temperate trees differ in their short-term strategies of controlling water flux in the soil-plant atmosphere continuum under field conditions and to predict more precisely how different tree species will respond to a future drier climate.

\section{MATERIALS AND METHODS}

\subsection{Study area}

The study was conducted in a temperate mixed broad-leaved forest in the Hainich National Park in western Thuringia, Central Germany $\left(51^{\circ} 04^{\prime} \mathrm{N}, 10^{\circ} 30^{\prime} \mathrm{E}\right)$. The Hainich is a forested plateau range (350 $\mathrm{m}$ a.s.1.) that encompasses an area of $22000 \mathrm{ha}$, constituting the largest non-fragmented beech-woodland block on calcareous soil in Germany (Hiekel et al., 2004). Mean annual temperature recorded at the nearby Weberstedt meteorological station is $7.5^{\circ} \mathrm{C}$ and mean annual rainfall is $590 \mathrm{~mm}$ (Deutscher Wetterdienst, 2005).

In the study, we selected two individuals each of $F$. sylvatica, T. cordata, C. betulus, F. excelsior and A. pseudoplatanus with a maximum distance of $50 \mathrm{~m}$ to each other. The criteria used for tree selection were that trees were within a similar DBH size class (about 35 to $70 \mathrm{~cm}$ ) and that the tree crown was located within the upper canopy (Tab. I). To access the uppermost sun canopy we used a mobile canopy lifter (model DL30, Denka-Lift A/S, Denmark) that allowed reaching at $30 \mathrm{~m}$ height.

The investigation was conducted between July and October 2006. Diurnal measurements were related to solar time which is $80 \mathrm{~min}$ behind of Central European Summer Time (CEST).

\subsection{Microclimatic measurements}

Hourly values of precipitation, global radiation, air temperature and relative air humidity for the whole year 2006 were obtained from the weather station Weberstedt/Hainich (Meteomedia $\mathrm{GmbH}$ ) located about $2 \mathrm{~km}$ from the study plot. Additionally, for calculating vapor pressure deficit $D$ directly above the crown of the study trees, we measured air temperature and relative air humidity in the upper canopy at the study plot with a Rotronic temperature and humidity probe (MP 100A Hygromer, Rotronic, Ettlingen, Germany). Measurements were taken every $15 \mathrm{~s}$ and stored as half-hourly means in a Campell CR10X data logger (Campbell Scientific, UK). To compare tree water status to the variation in climatic parameters on a daily scale, we removed the effect of different day lengths and used the daytime mean of $D$.

\subsection{Soil water content and soil water potential}

Volumetric soil water content $\left(\Theta_{\mathrm{V}}\right.$, vol. \%) was measured with TDR sensors installed at three different depths $(10,30$ and $50 \mathrm{~cm})$ in 
Table I. Biometric data of all studied trees: diameter at breast height $(\mathrm{DBH})$, tree height $(H)$, basal area $\left(A_{B}\right)$, average leaf size $(\mathrm{LS})$ and specific leaf area (SLA). LS and SLA are means of $n=35$ and $n=44$ leaves collected from the upper crown, respectively. Values in parentheses are the standard error.

\begin{tabular}{lccccc}
\hline Species & DBH $(\mathrm{cm})$ & $H(\mathrm{~m})$ & $A_{B}\left(\mathrm{~cm}^{2}\right)$ & $\mathrm{LS}_{\left(\mathrm{cm}^{2}\right)}$ & $\left.\mathrm{SLA}_{(\mathrm{cm}}^{2} \mathrm{~g}^{-1}\right)$ \\
\hline A. pseudoplatanus \#1 & 77.7 & 34.5 & 4737.7 & $75.16(3.38)$ & $80.81(1.3)$ \\
A. pseudoplatanus \#2 & 53.8 & 29.0 & 2272.8 & $76.40(5.02)$ & $127.50(3.35)$ \\
F. sylvatica \#1 & 40.1 & 29.2 & 1263.4 & $16.41(0.57)$ & $107.01(2.86)$ \\
F. sylvatica \#2 & 48.4 & 32.5 & 1838.6 & $22.54(0.8)$ & $112.95(4.12)$ \\
F. excelsior \#1 & 39.5 & 27.4 & 1223.6 & $165.74(6.33)$ & $105.11(3.74)$ \\
F. excelsior \#2 & 35.0 & 26.3 & 962.9 & $171.04(7.04)$ & $109.66(5.97)$ \\
C. betulus \#1 & 34.4 & 24.3 & 928.2 & $24.26(0.56)$ & $114.21(2.45)$ \\
C. betulus \#2 & 37.2 & 24.7 & 1089.3 & $30.57(0.91)$ & $137.16(7.29)$ \\
T. cordata \#1 & 40.1 & 28.9 & 1263.4 & $30.15(1.39)$ & $138.83(8.58)$ \\
T. cordata \#2 & 64.6 & 33.6 & 3279.3 & $23.57(0.74)$ & $128.90(4.8)$ \\
\hline
\end{tabular}

close proximity to the studied trees. Between July and October 2006, two measurements were taken per day (0:00h and 12:00h).

Soil matrix potential $\left(\Psi_{\mathrm{s}}, \mathrm{MPa}\right)$, which is a more important parameter to asses plant response to soil drought than volumetric soil water content, could not be measured with tensiometers because of low $\Psi_{\mathrm{S}}$ values (beyond the measuring range of the tensiometers) during part of the study period. Instead, we used the program Rosetta Lite Version 1.0 (Schaap et al., 1998) to calculate soil water potential from soil water content $\left(\Theta_{\mathrm{v}}\right)$ data. Necessary soil parameters (e.g. clay content, bulk density) were provided by Guckland et al. (2008).

\subsection{Leaf water potential, transpiration rate and leaf conductance}

Leaf water potential ( $\left.\Psi_{\mathrm{L}}, \mathrm{MPa}\right)$ was measured with a Scholander pressure chamber (Scholander et al., 1965). Leaf (or shoot) samples were collected from the exposed sun crown of the 10 selected trees. Predawn leaf water potential $\left(\Psi_{\mathrm{pd}}, \mathrm{MPa}\right)$ was measured before sunrise between 2:00h and 4:30h. Noon leaf water potential ( $\left.\Psi_{\text {noon }}, \mathrm{MPa}\right)$ was recorded between 12:00h and 13:30h. Three to four leaf (shoot) samples were measured per tree.

Leaf transpiration $\left(E, \mathrm{mmol} \mathrm{m} \mathrm{m}^{-2} \mathrm{~s}^{-1}\right)$ and leaf conductance $\left(g_{\mathrm{L}}\right.$, mmol m $\mathrm{m}^{-2} \mathrm{~s}^{-1}$ ) were measured with a Li-Cor-1600M steady state porometer (Li-Cor, Lincoln Nebraska, USA). We conducted measurements between 6:00 and 7:00, 9:00 and 10:00, 12:00 and 13:00, 15:00 and 16:00h. Each time we sampled ten leaves per tree from the upper sun crown. Per field working day, we were able to measure 3 or 4 different trees synchronously because of the limited mobility range of the canopy lifter. To complete measurements in all 10 trees we needed three consecutive days with similar light conditions. Four complete field campaigns and additional single-day measurements could be conducted between July and September 2006, a period which included contrasting soil moisture conditions.

\subsection{Xylem sap flux}

Sap flux density in the stem $\left(J_{\mathrm{s}}, \mathrm{g} \mathrm{m}^{-2} \mathrm{~s}^{-1}\right)$ was monitored with the constant-heat method after Granier (1987). Two $20 \mathrm{~mm}$-long Graniertype probes were inserted at a distance of $15 \mathrm{~cm}$ from each other at lower and higher insertion points into the stem at $1.3 \mathrm{~m}$ height. The upper probe was constantly heated $(200 \mathrm{~mW})$, while the lower one served for monitoring the reference temperature of the stem. The temperature difference between the heated and the reference probe was recorded continuously and related to the maximum temperature difference occurring at predawn when minimum or no flow occurred. Sap flux density was calculated according to the empirical equation given by Granier (1987). To avoid disturbance by thermal gradients or stem flow runoff at the measuring points, the sensors were insulated by polystyrene mats and covered with a reflecting foil and a transparent plastic cover. Sap flux data were logged every $30 \mathrm{~s}$ and a mean value was recorded every $30 \mathrm{~min}$. Half-hourly sap flux density values were summed to obtain daily flux density in $\mathrm{g} \mathrm{cm}^{-2} \mathrm{~d}^{-1}$. We used data from a prior study (Gebauer et. al., 2008) which investigated radial patterns and changes in sapwood area with tree size of the same tree species at the same forest site. No corrections of sap fluxes as suggested by Clearwater et al. (1999) were necessary for our study trees.

\subsection{Whole-tree hydraulic conductance}

The amount of water which flows under a given pressure gradient through a tree is determined by the hydraulic conductance $\left(L_{\mathrm{c}}\right.$, $g \mathrm{MPa}^{-1} \mathrm{~s}^{-1} \mathrm{~m}^{-2}$ ) of the flow path between soil and leaf, and the water potential gradient along this flow path. $L_{\mathrm{c}}$ was calculated from $J_{\mathrm{s}}$ and the difference in $\Psi_{\mathrm{pd}}$ and $\Psi_{\text {noon }}$ after Loustau and Granier (1993) and Pataki et al. (2000). We used $J_{\mathrm{s}}$ data that were recorded synchronously to the $\Psi_{\text {noon }}$ values. $L_{\mathrm{c}}$ was calculated as follows:

$$
L_{\mathrm{c}}=\frac{J_{\mathrm{s}}}{\left(\Psi_{\mathrm{pd}}-\Psi_{\text {noon }}\right)} \text {. }
$$

\subsection{Statistical analyses}

The data sets showed a non-Gaussian distribution according to a Shapiro \& Wilk test. Parameters of leaf morphology were compared pairwise among species with the Wilcoxon U-Test after Mann $\&$ Whitney. The relationship between $D$ or $\Psi_{\mathrm{S}}$ and $\Psi_{\mathrm{L}}, g_{\mathrm{L}}$ and $J_{\mathrm{sd}}$ was analyzed with linear and non-linear regressions using the program Xact 7.20g (SciLab GmbH, Hamburg, Germany). All other calculations were conducted with SAS statistical software, version 8.02 (SAS Institute, Cary, NC, USA). Significance was determined at $p \leqslant 0.05$ in all tests. 


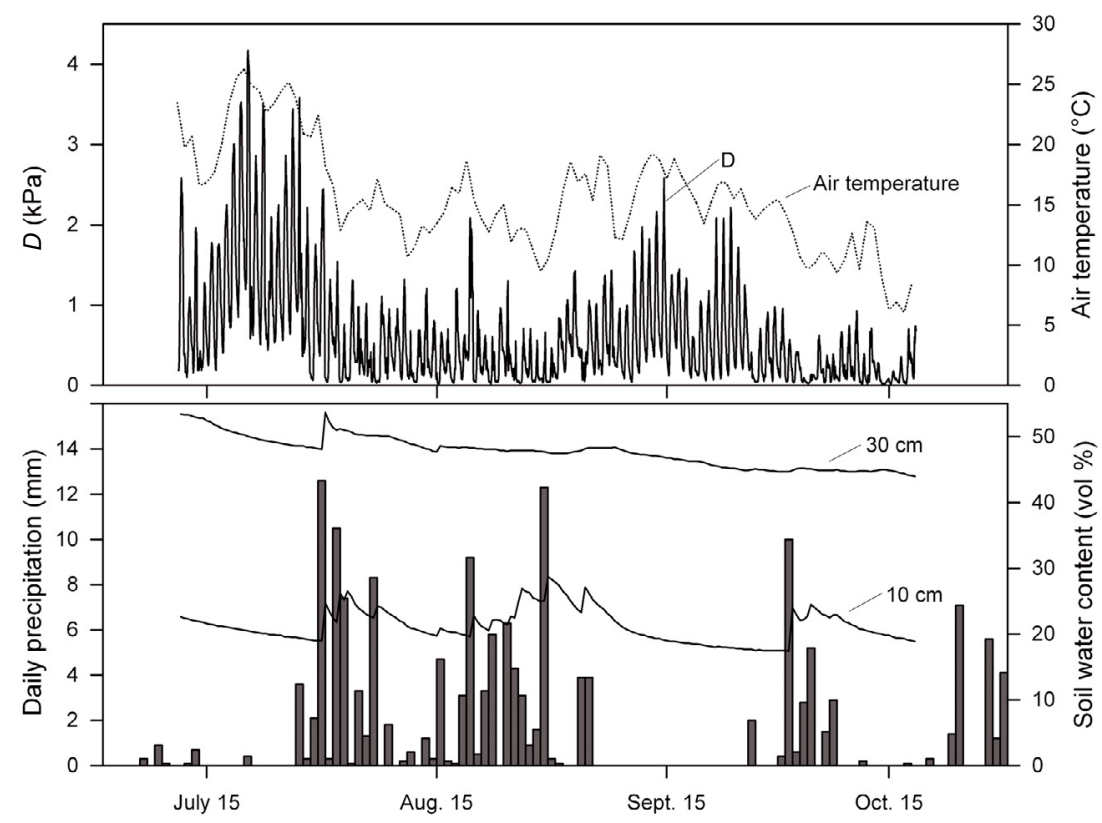

Figure 1. Top: Seasonal courses of vapor pressure deficit $(D)$ and air temperature (daily means) from July to October 2006. Bottom: Daily precipitation $(P$, bars $)$ and soil moisture content $\left(\Theta_{\mathrm{V}}\right)$ at 10 and $30 \mathrm{~cm}$ depth during the study period.

\section{RESULTS}

\subsection{Climate conditions and soil water content}

The daily means of air temperature during the study period (July 11th to October 18th, 2006) varied between 6 and $26^{\circ} \mathrm{C}$ (Fig. 1) which was higher than the average except in August. During the second half of July, $D$ achieved highest values with about $4 \mathrm{kPa}$ (Fig. 1). In September, $D$ declined due to lower temperatures. Annual precipitation in 2006 was $72 \mathrm{~mm}$ less than the long-term precipitation average $(590 \mathrm{~mm})$. July and September were almost rainless months, while rainfall was relatively high in August. At $30 \mathrm{~cm}$ soil depths, $\Theta_{\mathrm{V}}$ decreased continuously from $54 \mathrm{vol}$. \% to $44 \mathrm{vol}$. \% between mid July and mid October, only interrupted by an infiltration event at the beginning of August. In contrast, $\Theta_{\mathrm{V}}$ closely followed the rainfall events at $10 \mathrm{~cm}$ depth (Fig. 1). During the dry periods in July and September, $\Theta_{\mathrm{V}}$ at $10 \mathrm{~cm}$ decreased continuously from 29 to 17 vol. \%.

\subsection{Biometric data}

Biometric characteristics of the studied trees are shown in Table I. Diameter at breast height (DBH) of the trees varied between $34.4 \mathrm{~cm}$ and $77.7 \mathrm{~cm}$ and tree height ranged from 24.3 to $34.5 \mathrm{~m}$. Leaf size and specific leaf area (SLA) showed considerable species-specific differences: $T$. cordata and $C$. betulus had a significantly higher SLA than the other species, A. pseudoplatanus had the smallest value. SLA between individuals of the two A. pseudoplatanus differed considerably (80.81 and 127.5). This is probably due to the spatial position of the two trees in the canopy.

\subsection{Leaf conductance and leaf water potential in their dependence on soil and atmospheric water status}

The five species differed considerably with respect to the daily maxima of leaf conductance $\left(g_{\mathrm{L}}\right)$ that were observed in sun canopy leaves during the study period. Peak values of $g_{\mathrm{L}}$ reached $270-280 \mathrm{mmol} \mathrm{m}^{-2} \mathrm{~s}^{-1}$ in F. excelsior and C. betulus, and $250 \mathrm{mmol} \mathrm{m}^{-2} \mathrm{~s}^{-1}$ in T. cordata, but did not exceed $150-170 \mathrm{mmol} \mathrm{m}^{-2} \mathrm{~s}^{-1}$ in A. pseudoplatanus and F. sylvatica (Fig. 2). Daily maxima of $g_{\mathrm{L}}$ decreased linearly with a decrease in soil matrix potential at $10 \mathrm{~cm}$ depth $\left(\Psi_{\mathrm{s}}\right)$ in all species except for F. excelsior; however, the slope of the conductance decrease was steeper in the species with higher maximum $g_{\mathrm{L}}$ (T. cordata and C. betulus) than in F. sylvatica and A. pseudoplatanus with low maximum $g_{\mathrm{L}}$ (Fig. 2). Higher maximum conductances were associated with much higher day-to-day variation in $g_{\mathrm{L}}$ levels as is visible when comparing the plots of T. cordata and A. pseudoplatanus in Figure 2.

Leaf conductance decreased exponentially with increasing atmospheric saturation deficit $(D)$ in the species with high maximum $g_{\mathrm{L}}$ (F. excelsior, T. cordata and $C$. betulus), but showed a more gentle decrease in F. sylvatica and A. pseudoplatanus, the two species with low maximum $g_{\mathrm{L}}$ (Fig. 3).

The water potential of sun canopy leaves measured at noon $\left(\Psi_{\text {noon }}\right)$ responded differently to increasing soil drought in the five tree species. We assumed the same matrix potential in the soil for all species because of the absence of a clear spatial segregation of the rooting systems of these species in the study area (Meinen, 2008). In C. betulus and T. cordata, $\Psi_{\text {noon }}$ remained unchanged upon a decrease in soil matrix potential from -0.05 to $-0.17 \mathrm{MPa}$, while $\Psi_{\text {noon }}$ significantly decreased from -2.0 to $-2.5 \mathrm{MPa}$ in $F$. sylvatica with increasing soil drought (Fig. 4). No trend was visible in the $\Psi_{\text {noon }}$ 


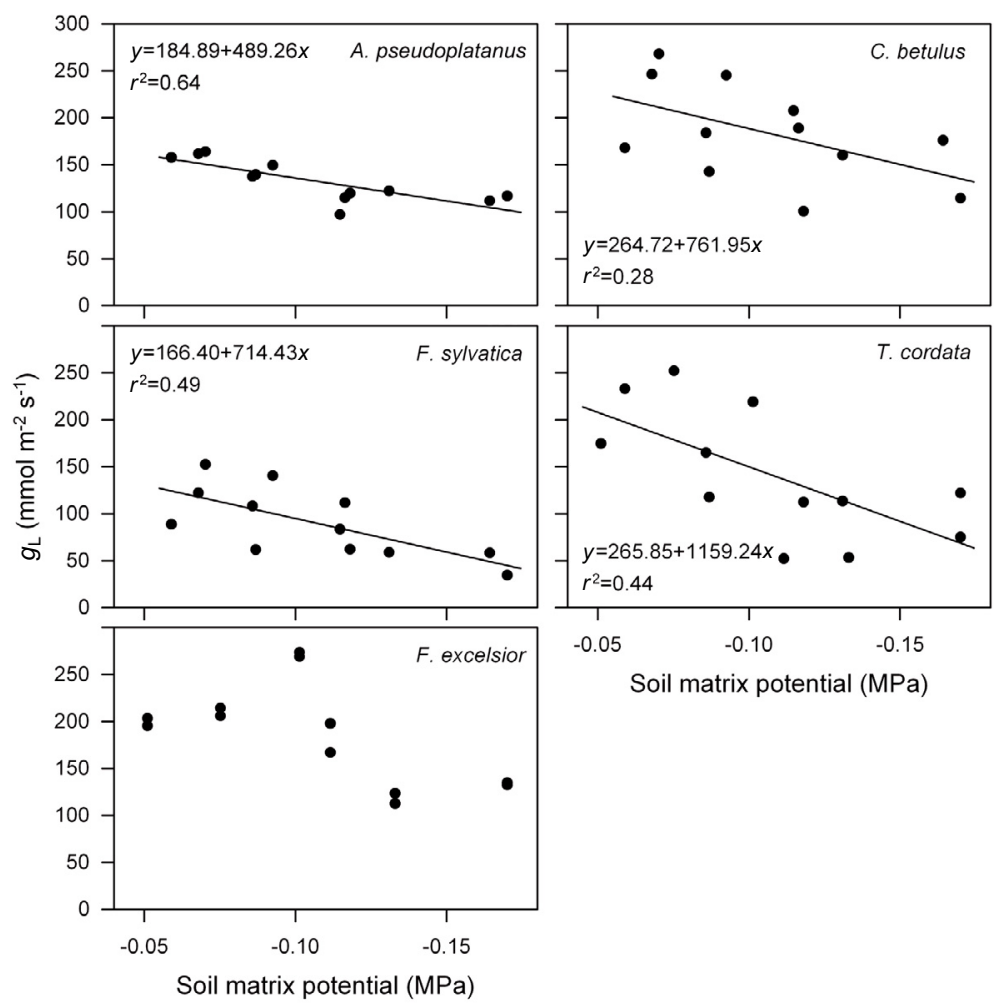

Figure 2. Relationship between daily maxima of leaf conductance $\left(g_{\mathrm{L}}\right)$ and the corresponding soil matrix potential $\left(\Psi_{\mathrm{s}}\right)$ at $10 \mathrm{~cm}$ depth for the five studied tree species. Values are means of $n=10$ sampled leaves (per individual).

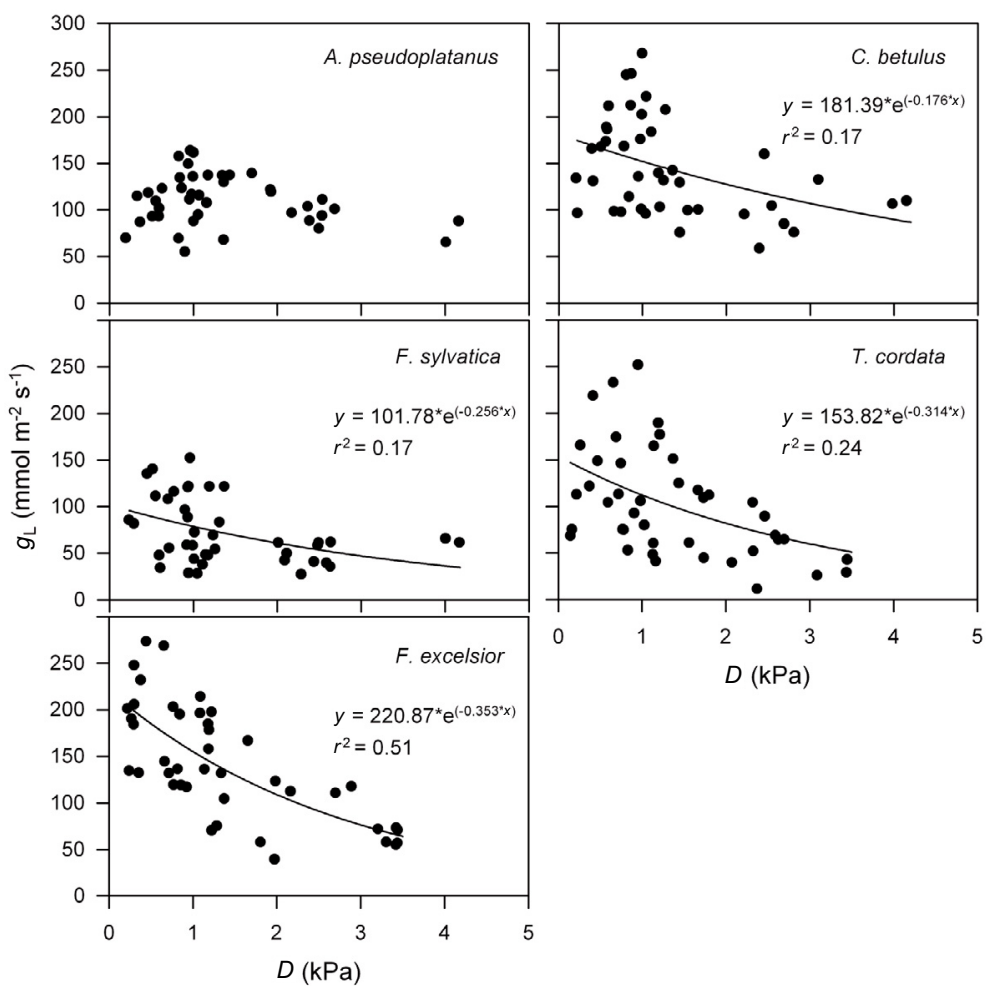

Figure 3. Leaf conductance $\left(g_{\mathrm{L}}\right)$ as a function of vapor pressure deficit $(D)$ for the five tree species in data sets of up to 43 measurements taken between July and September 2006. All regressions are significant $(p<0.05)$ except for that of A. pseudoplatanus. 


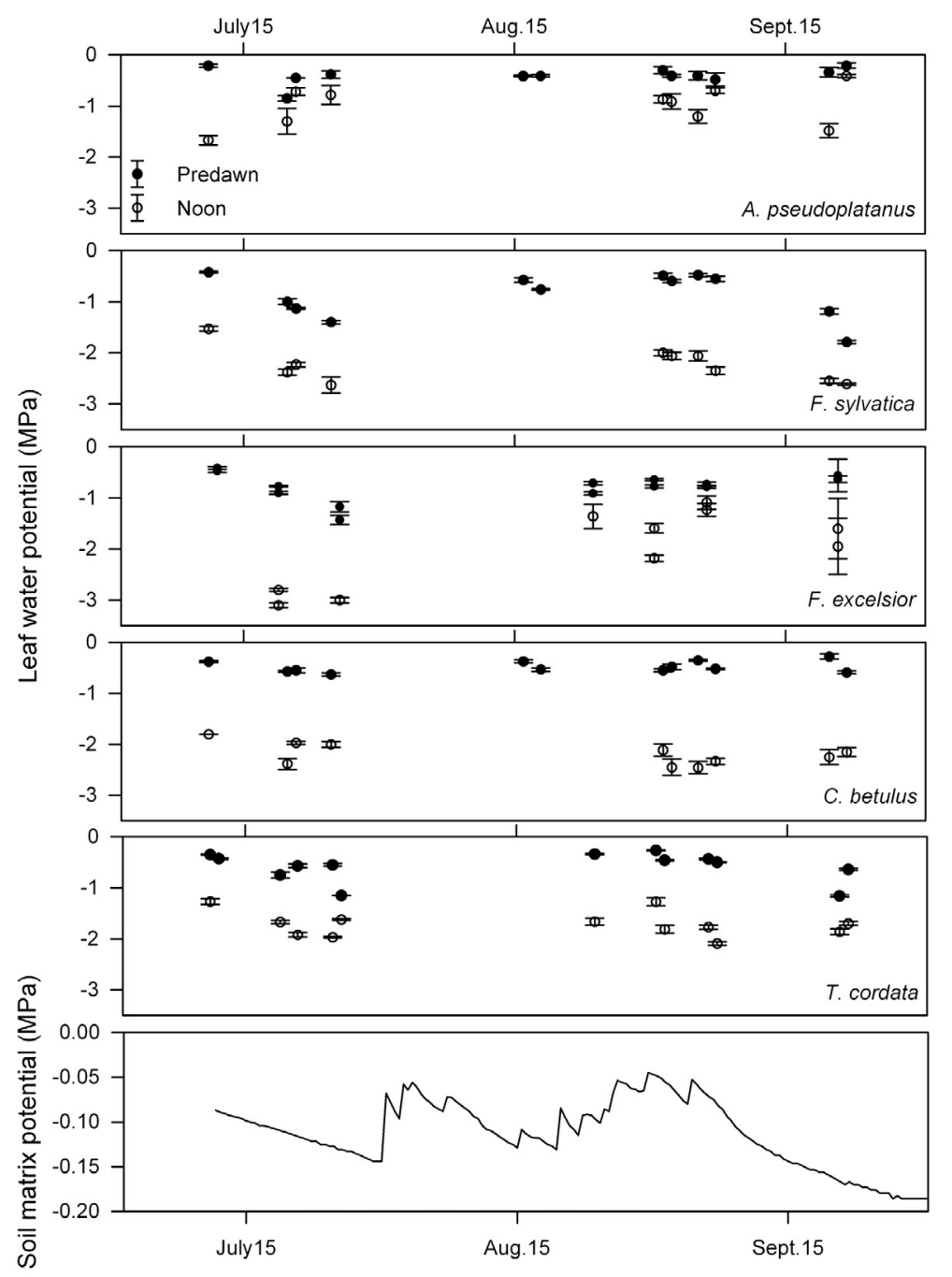

Figure 4. Seasonal course of predawn and noon leaf water potential ( $\Psi_{\mathrm{pd}}$ and $\left.\Psi_{\text {noon }}\right)$ for the five studied tree species. Error bars indicate the standard error $(n=3-4)$. Bottom: Seasonal course of soil matrix potential $\left(\Psi_{\mathrm{S}}\right)$ at $10 \mathrm{~cm}$ soil depth.

values of $A$. pseudoplatanus and $F$. excelsior, but the dayto-day fluctuation in leaf water potential minima was much higher in these two species than in C. betulus, $T$. cordata and $F$. sylvatica. Lowest $\Psi_{\text {noon }}$ values were measured in $F$. excelsior $(<-3.0 \mathrm{MPa})$, followed by $F$. sylvatica $(-2.6 \mathrm{MPa})$ and C. betulus (-2.5 MPa) while $A$. pseudoplatanus differed from the other species because of its high daily $\Psi_{\text {noon }}$ which typically did not fall below $-1.5 \mathrm{MPa}$ (Fig. 4). The species also contrasted with respect to the daily leaf water potential maxima (predawn value, $\Psi_{\mathrm{pd}}$ ): A. pseudoplatanus and $C$. betulus maintained high predawn potentials (typically $>-0.5 \mathrm{MPa}$ ) in the sun canopy throughout the measuring season with no significant effect of drought. Similarly, $\Psi_{\mathrm{pd}}$ of $F$. excelsior did not decrease upon a decrease in soil matrix potential, but the day-to-day variation was considerable. In contrast, $F$. sylvatica and $T$. cordata exhibited a significant and (in beech) steep decrease of $\Psi_{\mathrm{pd}}$ with a drop in $\Psi_{\mathrm{S}}$ from -0.05 to $-0.17 \mathrm{MPa}$ (Fig. 4). The lowest absolute minima of $\Psi_{\mathrm{pd}}$ were recorded in F. sylvatica $(-1.79 \mathrm{MPa})$.

\subsection{Xylem sap flux response to soil and atmospheric water status}

The five tree species showed rather similar average and maximum xylem sap flux densities in the stem $\left(J_{\text {sd }}\right.$, flux density per day) during the study period (Tab. II). Remarkably, ring-porous $F$. excelsior differed not significantly from the four diffuse-porous species. Highest flux densities were observed in C. betulus \#1 with $171.4 \mathrm{~g} \mathrm{~cm}^{-2} \mathrm{~d}^{-1}$. We observed large differences in the average flux density between different trees of a species ( $F$. sylvatica and $C$. betulus, Tab. II) in spite of the similar tree sizes. We suspect that these differences may be due the location of the flux sensors in sapwood areas with different conductivities.

A decrease of soil matrix potential from -0.08 to $-0.18 \mathrm{MPa}$ reduced xylem sap flux to about a third in A. pseudoplatanus, F. sylvatica and C. betulus, and to about the half in T. cordata (Fig. 5). In contrast, no decrease in xylem sap flux with increasing soil drought occurred in F. excelsior, but $J_{\text {sd }}$ rather 


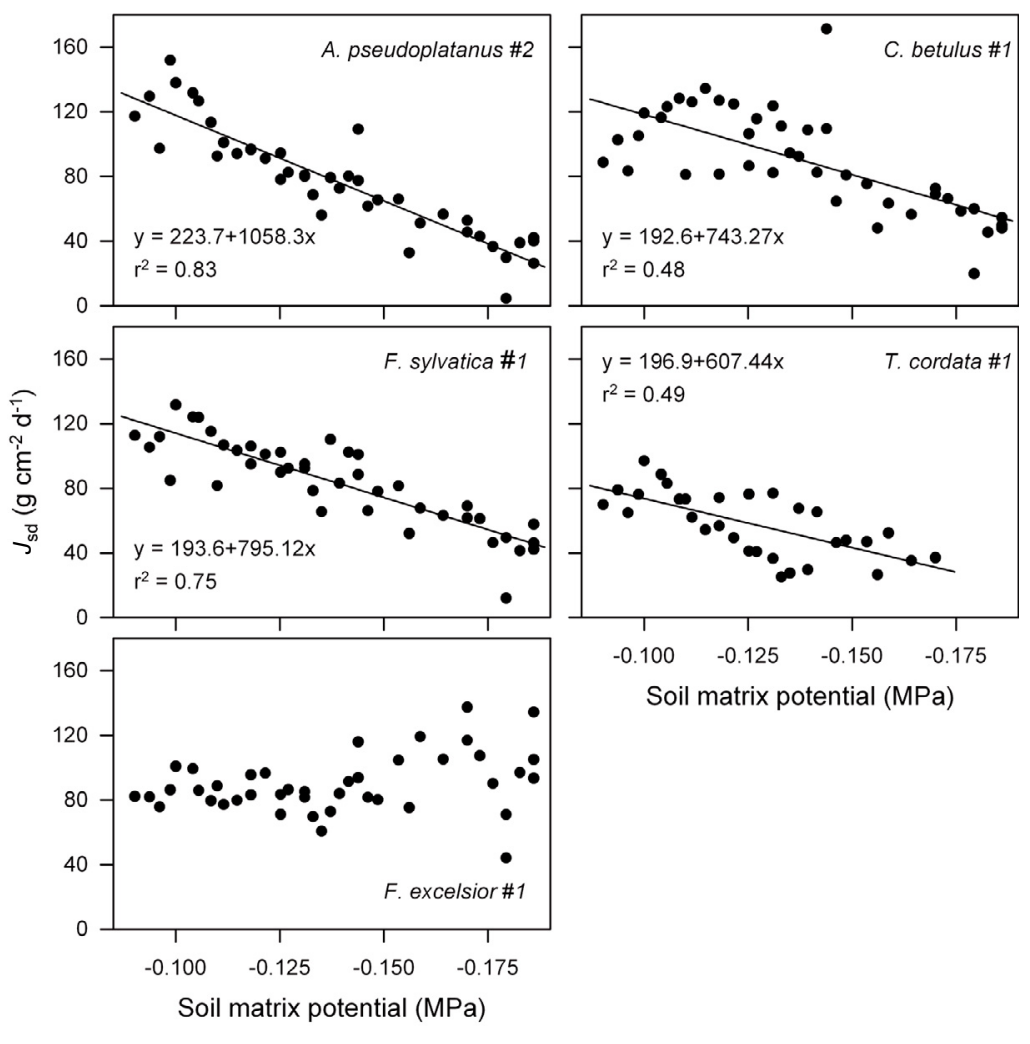

Figure 5. Daily sap flux density $\left(J_{\mathrm{sd}}\right)$ as a function of the soil matrix potential $\left(\Psi_{\mathrm{S}}\right)$ at $10 \mathrm{~cm}$ soil depth. One individual each of the five species is shown. Values correspond to the dry periods in July (July 12-July 30, 2006) and September (Sept. 08-Sept. 30, 2006). For trees with a significant correlation $(p<0.05)$, the linear regression lines are drawn.

tended to increase at soil matrix potentials $<-0.15 \mathrm{MPa}$, while the data showed increasing variability. The spread in $J_{\text {sd }}$ values towards decreasing soil matrix potential coincided with a lack of a relationship between $J_{\text {sd }}$ and $D$ under soil drought (Fig. 6). This may indicate a lack of stomatal control; however, we had very few data of $g_{\mathrm{L}}$ at low $\Psi_{\mathrm{S}}$ to confirm this theory.

The response of $J_{\text {sd }}$ to variable atmospheric saturation deficits was studied with data sets from a "wet period" with soil water contents $>21 \mathrm{vol}$. $\%$ and soil matrix potentials $>$ $-0.107 \mathrm{MPa}$, and from a "dry period" with $\Theta_{\mathrm{s}}<21$ vol. \% and $\Psi_{\mathrm{S}}<-0.107 \mathrm{MPa}$. At this threshold soil moisture, leaf water potential and sap flux density were found to decrease significantly in the majority of species (Fig. 4). The dependence of $J_{\text {sd }}$ on $D$ was described with logarithmic functions for the wet and the dry period in the five species in Figure 6. In all species, the relationship was stronger in the wet than in the dry period as reflected in higher coefficients of determination $\left(r^{2}\right)$ and also in steeper slopes. In the case of $T$. cordata \#1 and $F$. excelsior $\# 1$, no significant $J_{\mathrm{sd}} / D$-relationship appeared in the dry period.

Based on sap flux data (measured around noon) and corresponding $\Psi_{\text {noon }}$ and $\Psi_{\mathrm{pd}}$, we calculated maximum $L_{\mathrm{c}}$ of the flow path soil-to-leaf in the five species (Tab. II). In T. cordata, $C$. betulus, F. excelsior and F. sylvatica, we obtained conductivities in the range of 0.82 to $2.88 \mathrm{~mol} \mathrm{~m}^{-2} \mathrm{~s}^{-1} \mathrm{MPa}^{-1}$ in the wet period and of 0.53 to $0.99 \mathrm{~mol} \mathrm{~m}^{-2} \mathrm{~s}^{-1} \mathrm{MPa}^{-1}$ in the dry period, respectively. Thus, $L_{\mathrm{c}}$ was markedly smaller in the dry period in all species. An exception was the tree F. sylvatica \#2, which had unusually small conductivities in both the dry and the wet period $\left(0.45\right.$ and $\left.0.36 \mathrm{~mol} \mathrm{~m}^{-2} \mathrm{~s}^{-1} \mathrm{MPa}^{-1}\right)$. A. pseudoplatanus differed from all other tree species by having significantly higher $L_{\mathrm{c}}$ values both in the wet and the dry period (Tab. II).

\section{DISCUSSION}

\subsection{Species differences in leaf conductance and leaf water potential}

Our measurements in sun canopy leaves of adult trees revealed considerable differences in maximum $g_{\mathrm{L}}$ among the five co-occurring tree species. High peak $g_{\mathrm{L}}$ values (up to $280 \mathrm{mmol} \mathrm{m}^{-2} \mathrm{~s}^{-1}$ ) were recorded in C. betulus, F. excelsior and $T$. cordata. These species are known to be drought-tolerant and to have large distribution ranges that include continental Eastern Europe (Ellenberg and Leuschner, 2009). In contrast, the drought-sensitive species $F$. sylvatica and A. pseudoplatanus with known distribution range restricted to sub-oceanic Central and Western Europe (Ellenberg and Leuschner, 2009) reached $g_{\mathrm{L}}$ maxima not higher than 160 to $180 \mathrm{mmol} \mathrm{m}^{-2} \mathrm{~s}^{-1}$. These values are closed to the $g_{\mathrm{L}}$ means given by Körner (1994) for temperate forest. Higher $g_{\mathrm{L}}$ in adult F. sylvatica 


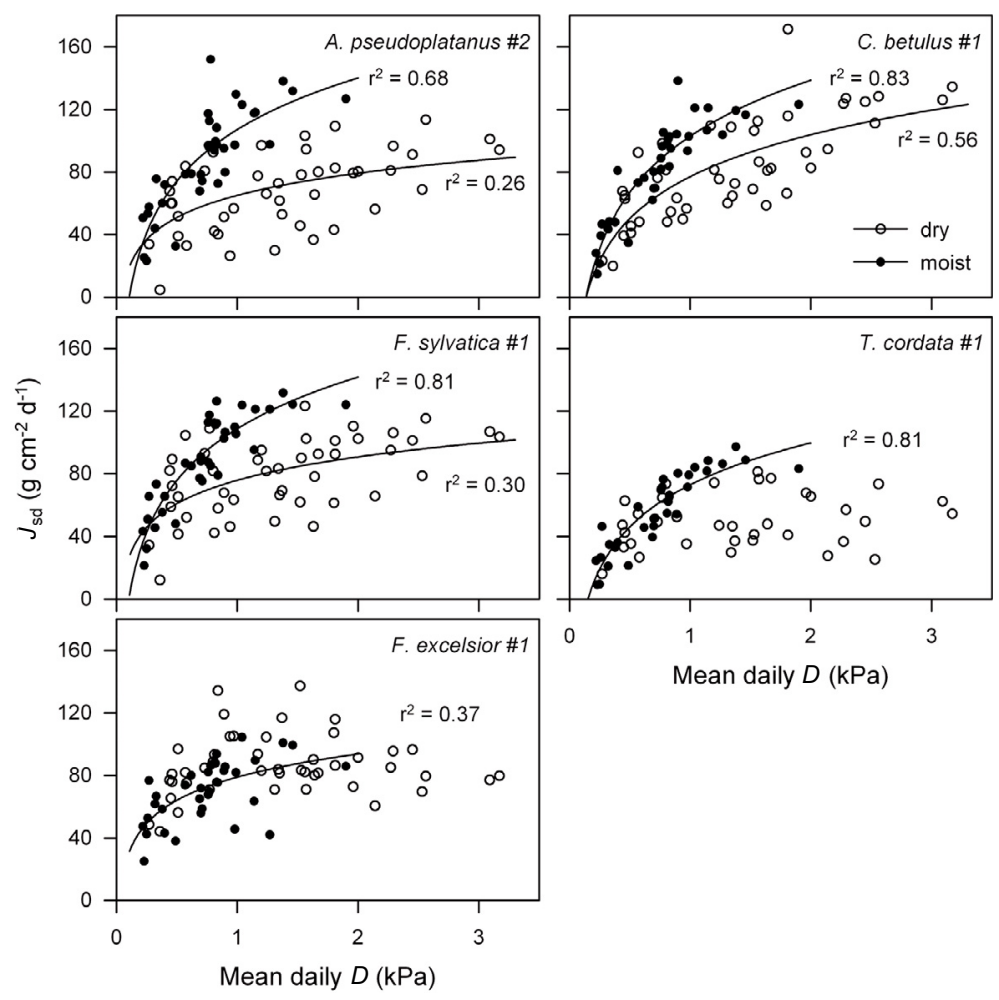

Figure 6. Daily sap flux density $\left(J_{\mathrm{sd}}\right)$ as a function of vapor pressure deficit $(D)$ for periods with high (filled circles) and low (open circles) soil moisture content $\left(\Theta_{\mathrm{V}}\right)$. Periods of different soil humidity were defined according to the criteria: $\left(\Theta_{\text {high }}>21\right.$ vol. \% $\left.>\Theta_{\text {low }}\right)$ or $\left(\Psi_{\mathrm{S} \text { high }}>\right.$ $\left.-0.107 \mathrm{MPa}>\Psi_{\mathrm{S} \text { low }}\right)$. For each species, one individual is shown. For trees with a significant relationship $(p<0.05)$ logarithmic functions of the type $y=a+b \times \ln (D)$ are drawn.

Table II. Mean values of daily sap flux density $\left(J_{\mathrm{sd}}\right)$, hydraulic conductivity $\left(L_{\mathrm{c}}\right)$ and leaf conductance $\left(g_{\mathrm{L}}\right)$ of all studied trees during wet and dry periods. For comparison, the maximum value of each tree recorded over the whole study period is given as well. Wet and dry periods are defined by soil moistures $>21$ or $<21$ vol. $\%$. In the dry period, air temperature and saturation deficit were generally higher than in the wet period, resulting partly in higher fluxes (* means $n=1$ ).

\begin{tabular}{|c|c|c|c|c|c|c|c|c|c|}
\hline \multirow{2}{*}{ Species } & \multicolumn{3}{|c|}{$J_{\mathrm{sd}}\left(\mathrm{g} \mathrm{cm}^{-2} \mathrm{~d}^{-1}\right)$} & \multicolumn{3}{|c|}{$L_{\mathrm{c}}\left(\mathrm{mol} \mathrm{m} \mathrm{m}^{-2} \mathrm{~s}^{-1} \mathrm{MPa}^{-1}\right)$} & \multicolumn{3}{|c|}{$g_{\mathrm{L}}\left(\mathrm{mmol} \mathrm{m}^{-2} \mathrm{~s}^{-1}\right)$} \\
\hline & Max. & Wet & Dry & Max. & Wet & Dry & Max. & Wet & Dry \\
\hline A. pseudoplatanus \#1 & 103.0 & 66.5 & 65.2 & 3.95 & 2.95 & $2.60 *$ & 164.1 & 158.6 & 104.5 \\
\hline A. pseudoplatanus \#2 & 152.0 & 87.7 & 67.9 & 10.87 & 5.10 & 3.27 & 157.9 & 145.1 & 119.7 \\
\hline F. sylvatica \#1 & 131.7 & 89.2 & 78.7 & 1.37 & 1.30 & 0.99 & 152.6 & 138.5 & 71.2 \\
\hline F. sylvatica \#2 & 123.2 & 21.0 & 31.1 & $0.45^{*}$ & 0.36 & $0.45^{*}$ & 108.5 & 86.4 & 52.0 \\
\hline F. excelsior \#1 & 137.4 & 70.2 & 86.4 & 4.09 & 1.91 & 0.57 & 273.8 & 230.6 & 150.2 \\
\hline F. excelsior \#2 & 96.8 & 56.6 & 64.5 & 4.88 & 2.88 & 0.69 & 269.1 & 223.6 & 137.5 \\
\hline C. betulus \#1 & 171.4 & 81.7 & 82.3 & 1.02 & 0.95 & 0.78 & 268.3 & 253.4 & 192.0 \\
\hline C. betulus \#2 & 108.4 & 45.5 & 39.4 & 0.88 & 0.82 & 0.53 & 184.1 & 165.1 & 125.2 \\
\hline T. cordata \#1 & 97.2 & 55.1 & 50.0 & 1.25 & 1.06 & 0.57 & 252.3 & 215.4 & 60.3 \\
\hline T. cordata \#2 & 98.8 & 44.9 & 59.7 & 1.66 & 1.20 & 0.83 & 233.2 & 172.1 & 116.1 \\
\hline
\end{tabular}

trees (up to 250-290 mmol m $\mathrm{m}^{-2} \mathrm{~s}^{-1}$ ) have been reported by Backes (1996); Backes and Leuschner (2000); Roberts and Rosier (1994); Tognetti et al. (1995).

Our $g_{\mathrm{L}}$ for $C$. betulus are in the middle range of the values reported by Keel et al. (2007). They found mean maximum $g_{\mathrm{L}}$ between 100 and $300 \mathrm{mmol} \mathrm{m} \mathrm{m}^{-2}$ in a four-year period with the lowest values reported during the dry year 2003. For T. cordata, our diurnal mean maximum $g_{\mathrm{L}}$ values agree with the measurements reported by Niinemets et al. (1999), and Sellin and Kupper (2007).

Differences between our measurements and literature data (both using leaf porometry) may reflect intraspecific variation in $g_{\mathrm{L}}$, or may be a consequence of reduced conductivities in dry summers, or might result from the investigation of different measuring objects (upper vs. lower canopy, large vs. small trees). 
Changes in $\Psi_{\mathrm{pd}}$ are a meaningful indicator of the development of plant water deficit during drought periods because it expresses the failure of a tree to compensate daytime water deficits during the night. For example, in beech, $\Psi_{\mathrm{pd}}$ values of $-1.66 \mathrm{MPa}$ have been considered as indicative of severe drought stress (Leuzinger et al., 2005). We recorded $\Psi_{\text {pd }}$ values as low as $-1.76 \mathrm{MPa}$ in beech which points to severe water shortage. Annual precipitation during 2006 was only $518 \mathrm{~mm}$.

Daily minima of $\Psi_{\text {noon }}$ in beech fell below the threshold value of -1.9 MPa determined by Hacke and Sauter (1995). Below this value beech shoots rapidly lost hydraulic conductivity due to embolism. However, Lemoine et al. (2002) reported significant variation in $\Psi_{\mathrm{L}}$ within the crown of beech trees and found that stomatal closure and the percentage of loss conductivity in the xylem was more than $50 \%$ in sun exposed branches only when $\Psi_{\mathrm{L}}$ dropped to almost $-2.5 \mathrm{MPa}$.

In F. excelsior, Lemoine et al. (2001) found the minimum threshold of leaf water potential to vary between -1.5 and $-2.8 \mathrm{MPa}$ depending on habitat, water supply and drought acclimation. Other authors reported loss of hydraulic conductivity starting with water potentials of $-2 \mathrm{MPa}$ (Cochard et al., 1997; Crombie et al., 1985). Thus, given the low water potentials measured in ash $(-3 \mathrm{MPa})$, cavitation in shoots most likely occurred during the study period. Much lower and highly variable $\Psi_{\mathrm{L}}$ have been reported by Carlier et al. (1992), with minima ranging between $-5.54 \mathrm{MPa}$ on shallow soils and $-1.94 \mathrm{MPa}$ on alluvial deposits. F. excelsior has an ample plasticity range of adaptation to wet and dry environments (Marigo et al., 2000).

During the whole study period, A. pseudoplatanus showed the highest $\Psi_{\mathrm{pd}}$ and $\Psi_{\text {noon }}$ values of the five species and the smallest daily water potential amplitudes $\left(\Psi_{\mathrm{pd}}-\Psi_{\text {noon }}\right)$. Korn (2004) reported similar values on sycamore. Lemoine et al. (2001) found remarkably high (less negative) daily minima of $\Psi_{\mathrm{L}}$ in $A$. pseudoplatanus which they explained by a high shoot hydraulic conductivity. This matches well to our findings of a particularly high root-to-leaf hydraulic conductivity in sycamore.

T. cordata and C. betulus did not reach their physiological drought limit in the Hainich forest. With $\Psi_{\text {pd }}$ minima not below $-1.0 \mathrm{MPa}$ and $\Psi_{\text {noon }}$ values at the lowest at $-2.09 \mathrm{MPa}$, T. cordata was above the threshold of $-2.1 \mathrm{MPa}$ for the beginning of wilting, leaf shedding and shoot growth reduction (Pigott and Pigott, 1993). C. betulus reached $\Psi_{\mathrm{pd}}$ minima of only $-0.7 \mathrm{MPa}$, which is much less than the predawn potentials of $-1.74 \mathrm{MPa}$ recorded by Leuzinger et al. (2005) in the dry summer 2003 in Switzerland.

\subsection{Interspecific variation in the relationship between xylem flux density and microclimate}

Our results of mean daily xylem flux density $\left(J_{\text {sd }}\right)$ in the five tree species are relatively low in comparison to the results obtained by Hölscher et al. (2005) in 2001 in a similar forest stand. They measured a mean daily $J_{\text {sd }}$ of $102 \mathrm{~g} \mathrm{~cm}^{-2} \mathrm{~d}^{-1}$ for sycamore, $86 \mathrm{~g} \mathrm{~cm}^{-2} \mathrm{~d}^{-1}$ for little-leaf linden, $77 \mathrm{~g} \mathrm{~cm}^{-2} \mathrm{~d}^{-1}$ for hornbeam and $67 \mathrm{~g} \mathrm{~cm}^{-2} \mathrm{~d}^{-1}$ for ash stems of comparable diameter. The summer of 2006 was, on average, drier than the summer of 2001 and thus resulted in lower mean $J_{\text {sd }}$ values in all species. In a very similar manner we found a linear decrease of $J_{\mathrm{sd}}$ with decreasing soil water content in sycamore, beech, hornbeam and little-leaf linden; however, the daily $J_{\text {sd }}$ values continued to decline below the minimum values found by Hölscher et al. (2005) in the wetter summer 2001. In the case of $F$. excelsior, it is remarkable that even under the much lower soil moisture of the summer 2006 the trees maintained constant $J_{\text {sd }}$ rates throughout the drought period with flux rates comparable to the values measured by Hölscher et al. (2005) under a more favorable moist soil water regime. It appears that continuous water supply is secured by the capacity of the species to develop low leaf water potentials and its ability to maintain a large and vital fine root system even during drought (Carlier et al., 1992; Korn, 2004; Stöhr and Lösch, 2004). Apparent hydraulic conductivity in the root-to-leaf flow path was not higher than in the other species, as we would have expected from a ring-porous tree.

The relationship between $J_{\text {sd }}$ and $D$ changed with increasing soil drought in all species except for F. excelsior. The characteristic plateau in $J_{\text {sd }}$ at high $D$ values which indicates stomatal regulation (Phillips et al., 1999) was reached at lower $D$ values under water shortage. This result and the negative relationship between $g_{\mathrm{L}}$ and soil matrix potential indicate that the stomatal regulation was directly or indirectly influenced by soil drought in sycamore, hornbeam and beech. In the case of little-leaf linden, it appears that the stomata lost their sensitivity to air humidity under soil drought resulting in low daily sap fluxes which did not respond to variation in $D$ during the whole drought period. Even though $g_{\mathrm{L}}$ was sensitive to $D$ in ash, no additional effect of soil drought could be observed in this species and no reduction in $J_{\text {sd }}$ occurred during dry periods. Several factors may allow this species to sustain constant transpiration rates throughout the growing season. First, the low $\Psi_{\text {noon }}$ values observed during the dry period indicate a high capacity of ash trees to absorb water even from relatively dry soils. Active osmotic adjustment during water shortage has been documented in this species by Guicherd et al. (1997), based on the accumulation of malate and mannitol in the leaf symplasm.

\subsection{Species adaptation to drought}

Despite the limited number of tree individuals investigated in our study, we shall attempt to classify the five species with respect to water consumption and drought tolerance strategies, based on own data and information in the literature.

Beech and sycamore respond sensitively to extended soil drought events and show a strong reduction in $J_{\mathrm{s}}$ and $E$ with decreasing soil water content. High $\Psi_{\mathrm{L}}$ with low daily and seasonal amplitudes and a high apparent $L_{\mathrm{c}}$ in the root-toleaf path characterize sycamore as a drought avoiding species (Tognetti et al., 1995). Beech can not avoid daily fluctuations in $\Psi_{\mathrm{L}}$ and often large and severe drops in $\Psi_{\mathrm{pd}}$ and $\Psi_{\text {noon }}$ during extended drought (Backes and Leuschner, 2000). We propose that high $J_{\text {sd }}$ and therefore a strongly decreasing $\Psi_{\text {noon }}$ 
despite of stomatal control ( $g_{\mathrm{L}}$ measured in the sun canopy) are partly responsible for the inability of beech to secure stable $\Psi_{\text {pd }}$ during soil drought. A low capacity of beech for active osmotic adjustment upon drought (Schipka, 2003) may aggravate symptoms of water shortage during dry periods.

A classification of hornbeam and little leaf linden with respect to their water consumption strategy is less clear. Both species revealed a high maximum $g_{\mathrm{L}}$ and lower effect of drought on stem increment (Frech, 2006) in the Hainich forest. Both traits would suggest the species to be drought tolerators. However, hornbeam and little leaf linden reduced $g_{\mathrm{L}}$ substantially with increasing $D$ and decreasing $\Psi_{\mathrm{s}}$ which would be elements of a drought avoiding strategy. Even though $T$. cordata is normally categorized as a drought tolerating species, our results provide evidence of a moderate sensitivity of this species to extended summer drought as is shown by the significant decrease in $\Psi_{\mathrm{pd}}$ upon soil drought. Therefore, in contrast to $C$. betulus, $T$. cordata must be classified as a partly droughtsensitive species, matching the assessment of Aasamaa et al. (2004).

The species which can deal best with prolonged drought period is European ash.

This species occurs in a broad variety of habitats, from occasionally flooded areas to xeric environments, and its ability to withstand drought is remarkable. The species can develop very low $\Psi_{\mathrm{L}}$ (up to $-6 \mathrm{MPa}$, Marigo et al. (2000)), and is able to maintain sufficient leaf conductance and $\mathrm{CO}_{2}$ assimilation during drought (Carlier et al., 1992; Guicherd et al., 1997; Korn, 2004; Marigo et al., 2000). A high maximum $g_{\mathrm{L}}$ and a low sensitivity of sap flow to water shortage are elements of a drought-tolerating strategy.

The Hainich forest represents a dry site with relative low annual precipitation $(590 \mathrm{~mm})$ and clay-rich soils which develop water shortage in summer. We believe that the droughtsensitive species $F$. sylvatica and A. pseudoplatanus are coming close to their drought tolerance limit at this site, hence trees exhibit reduced leaf conductance. Furthermore, the lower responsiveness of $g_{\mathrm{L}}$ to $D$ in beech and sycamore supports a common observation that species with inherently low or reduced leaf conductance are less sensitive to $D$ than species with a high maximum $g_{\mathrm{L}}$ (Meinzer, 2003; Oren et al., 1999). As a result of this work, the five species can be arranged with regard to their drought sensitivity at the leaf or canopy level in the sequence ash $<$ hornbeam $<$ little-leaf linden $<$ sycamore $<$ beech if the following tree responses are used as criteria of a low sensitivity: (i) to maintain $\Psi_{\text {pd }}$ at a high level during drought periods, (ii) to reach high leaf conductances in periods with not too dry soils, and (iii) to reduce sap flux only moderately upon soil drought. With an increase in the frequency and intensity of summer heat waves as is predicted for parts of Central Europe, species like ash and hornbeam will be in advantage over beech which dominates many forests today. However, the vitality and productivity of the five tree species does not only depend on the regulation of leaf water status, but is also a function of the drought sensitivity of stem growth and leaf and root production, and the success of rejuvenation under a drier climate.
Acknowledgements: We would like to acknowledge the good cooperation with the headquarters of the Hainich National Park, Thuringia. We also thank Hermann Jungkunst for his help with the calculation of soil matrix potentials. We further thank Sarah Haverstock for her help in the field, Heinz Coners for technical support and Dirk Deilke for his help in transporting the crown lift. This study was enabled by a scholarship granted through the Graduiertenkolleg 1086 "Biodiversity Functions in Temperate Forests" funded by Deutsche Forschungsgemeinschaft (DFG).

\section{REFERENCES}

Aasamaa K., Sober A., Hartung W., and Niinemets U., 2004. Drought acclimation of two deciduous tree species of different layers in a temperate forest canopy. Trees 18: 93-101.

Aranda I., Gil L., and Pardos J.A., 2000. Water relations and gas exchange in Fagus sylvatica L. and Quercus petraea (Mattuschka) Liebl. in a mixed stand at their southern limit of distribution in Europe. Trees 14: 344-352.

Backes K., 1996. Der Wasserhaushalt vier verschiedener Baumarten der Heide-Wald-Sukzession. Ph.D. thesis, Univ. Göttingen.

Backes K. and Leuschner C., 2000. Leaf water relations of competitive Fagus sylvatica and Quercus petraea trees during 4 years differing in soil drought. Can. J. For. Res. 30: 335-346.

Bolte A., Czajkowski T., and Kompa T., 2007. The north-eastern distribution range of European beech - a review. Forestry 80: 413-429.

Bovard B.D., Curtis P.S., Vogel C.S., Su H.B., and Schmid H.P., 2005. Environmental controls on sap flow in a northern hardwood forest. Tree Physiol. 25: 31-38.

Bréda N., Huc R., Granier A., and Dreyer E., 2006. Temperate forest trees and stands under severe drought: a review of ecophysiological responses, adaptation processes and long-term consequences. Ann. For. Sci. 63: 625-644.

Carlier G., Peltier J.P., and Gielly L., 1992. Water relations of ash (Fraxinus excelsior L.) in a mesoxerophilic mountain stand. Ann. Sci. For. 49: 207-223.

Clearwater M.J., Meinzer F.C., Andrade J.L., Goldstein G., and Holbrook N.M., 1999. Potential errors in measurements of nonuniform sap flow using heat dissipation probes. Tree Physiol. 19: 681-687.

Cochard H., Bréda N., and Granier A., 1996. Whole tree hydraulic conductance and water loss regulation in Quercus during drought: evidence for stomatal control of embolism? Ann. Sci. For. 53: 197-206.

Cochard H., Peiffer M., LeGall K., and Granier A., 1997. Developmental control of xylem hydraulic resistances and vulnerability to embolism in Fraxinus excelsior L: Impacts on water relations. J. Exp. Bot 48: 655-663.

Crombie D.S., Milburn J.A., and Hipkins M.F., 1985. Maximum sustainable xylem sap tensions in Rhododendron and other species. Planta 163: $27-33$.

Ellenberg H. and Leuschner C., 2009. Vegetation Mitteleuropas mit den Alpen in ökologischer, dynamischer und historischer Sicht. 6th Ed., Ulmer, Stuttgart, in press.

Frech A., 2006. Walddynamik in Mischwäldern des Nationalparks Hainich: Untersuchung der Mechanismen und Prognose der Waldentwicklung. Ph.D. thesis, Univ. of Göttingen.

Gebauer T., Horna V., and Leuschner C., 2008. Variability in radial sap flux density patterns and sapwood area among seven co-occurring temperate broad-leaved tree species. Tree Physiol. 28: 1821-1830.

Granier A., 1987. Evaluation of transpiration in a Douglas-fir stand by means of sap flow measurements. Tree Physiol. 3: 309-319. 
Granier A., Huc R., and Barigah S.T., 1996. Transpiration of natural rain forest and its dependence on climatic factors. Agric. For. Meteorol. 78: 19-29.

Guicherd P., Peltier J.P., Gout E., Bligny R., and Marigo G., 1997. Osmotic adjustment in Fraxinus excelsior L.: malate and mannitol accumulation in leaves under drought conditions. Trees 11: 155-161.

Guckland A., Brauns M., Flessa H., Thomas F.M., and Leuschner C., 2008. Acidity, nutrient stocks and organic matter content in soils of a temperate deciduous forest with different abundance of European beech (Fagus sylvatica L.). J. Plant Nutr. Soil Sci. (in press).

Hacke U. and Sauter J.J., 1995. Vulnerability of xylem to embolism in relation to leaf water potential and stomatal conductance in Fagus sylvatica f. purpurea and Populus balsamifera. J. Exp. Bot. 46: 11771183.

Hiekel W., Fritzlar F., Nöllert A., and Westhus W., 2004. Die Naturräume Thüringens. Naturschutzreport 21: 1-383.

Hölscher D., Koch O., Korn S., and Leuschner C., 2005. Sap flux of five co-occurring tree species in a temperate broad-leaved forest during seasonal soil drought. Trees 19: 628-637.

Keel S.G., Pepin S., Leuzinger S., and Körner C., 2007. Stomatal conductance in mature deciduous forest trees exposed to elevated $\mathrm{CO}_{2}$. Trees 21: 151-159.

Korn S., 2004. Experimentelle Untersuchungen der Wasseraufnahme und der hydraulischen Eigenschaften des Wurzelsystems von sechs heimischen Laubbaumarten. Ph.D. thesis, Univ. of Göttingen.

Körner C., 1994. Leaf diffusive conductances in the major vegetation types of the globe. In: Schulze E.D. and Caldwell M.M. (Eds.), Ecophysiology of photosynthesis. Springer, Berlin, Ecological Studies, Vol. 100, pp. 463-490.

Lemoine D., Peltier J.P., and Marigo G., 2001. Comparative studies of the water relations and the hydraulic characteristics in Fraxinus excelsior, Acer pseudoplatanus and A. opalus trees under soil water contrasted conditions. Ann. For. Sci. 58: 723-731.

Lemoine D., Cochard H., and Granier A., 2002. Within crown variation in hydraulic architecture in beech (Fagus sylvatica L.): evidence for a stomatal control of xylem embolism. Ann. For. Sci. 59: 19-27.

Leuzinger S., Zotz G., Asshoff R., and Körner C., 2005. Responses of deciduous forest trees to severe drought in Central Europe. Tree Physiol. 25: 641-650.

Loustau D. and Granier A., 1993. Environmental control of water flux through Maritime pine (Pinus pinaster Ait.). In: Borghetti J., Grace J., and Raschi A. (Eds), Water transport in plants under climatic stress. Cambridge University Press, Cambridge, pp. 205-218.

Magnani, F. and Borghetti M., 1995. Interpretation of seasonal changes of xylem embolism and plant hydraulic resistance in Fagus sylvatica. Plant Cell Environ. 18: 689-696.

Marek M., Masarovièová E., Kratochvílová I., Eliáš P., and Janouš P., 1989. Stand microclimate and physiological activity of tree leaves in an oak-hornbeam forest. II. Leaf photosynthetic activity. Trees 4: 234-240.

Marigo G., Peltier J.P., Girel J., and Pautou G., 2000. Success in the demographic expansion of Fraxinus excelsior L. Trees 15: 1-13.

Meehl G.A. and Tebaldi C., 2004. More intense, more frequent, and longer lasting heat waves in the 21st century. Science 305: 994-997.

Meinen C., 2008. Fine root dynamics in broad-leaved deciduous forest stands differing in tree species diversity. Ph.D. thesis, Univ. Göttingen.

Meinzer F.C., 2003. Functional convergence in plant response to the environment. Oecologia 134: 1-11.
Nardini A. and Salleo S., 2000. Limitation of stomatal conductance by hydraulic traits: sensing or preventing xylem cavitation? Trees 15 : $14-24$.

Niinemets U., Sober A., Kull O., Hartung W., and Tenhunen J.D., 1999. Apparent controls on leaf conductance by soil water availability and via light-acclimation of foliage structural and physiological properties in a mixed deciduous, temperate forest. Int. J. Plant Sci. 160: 707-721.

Oren R., Sperry J.S., Katul G.G., Pataki D.E., Ewers B.E., Phillips N., and Schäfer K.V.R., 1999. Survey and synthesis of intra- and interspecific variation in stomatal sensitivity to vapour pressure deficit. Plant Cell Environ. 22: 1515-1526.

Oren R., Sperry J.S., Ewers B.E., Pataki D.E., Phillips N., and Megonigal J.P., 2001. Sensitivity of mean canopy stomatal conductance to vapor pressure deficit in a flooded Taxodium distichum $\mathrm{L}$. forest: hydraulic and non-hydraulic effects. Oecologia 126: 21-29.

Pataki D.E. and Oren R., 2003. Species differences in stomatal control of water loss at the canopy scale in a mature bottomland deciduous forest. Adv. Water Res. 26: 1267-1278.

Pataki D.E., Oren R., and Smith W.K., 2000. Sap flux of co-occurring species in a western subalpine forest during seasonal soil drought. Ecology 81: 2557-2566.

Phillips N., Oren R., Zimmermann R., and Wright, S.J., 1999. Temporal patterns of water flux in trees and lianas in a Panamanian moist forest. Trees 14: 116-123.

Pigott C.D. and Pigott S., 1993. Water as a determinant of the distribution of trees at the boundary of the Mediterranean zone. J. Ecol. 81: 557566.

Roberts J. and Rosier P.T.W., 1994. Comparative estimates of transpiration of ash and beech forest at a chalk site in southern Britain. J. Hydrol. 162: 229-245.

Schaap M.G., Leij F.J., and van Genuchten, M.T., 1998. Neural network analysis for hierarchical prediction of soil hydraulic properties. Soil Sci. Soc. Am. J. 62: 847-855.

Schär C., Vidale P.L., Luthi D., Frei C., Haberli C., Liniger M.A., and Appenzeller C., 2004. The role of increasing temperature variability in European summer heatwaves. Nature 427: 332-336.

Schipka F., 2003. Blattwasserzustand und Wasserumsatz von vier Buchenwäldern entlang eines Niederschlagsgradienten in Mitteldeutschland. Ph.D. thesis, Univ. of Göttingen.

Scholander P.F., Hammel H.T., Bradstreet E.D., and Hemmingsen E.A., 1965. Sap pressure in vascular plants - negative hydrostatic pressure can be measured in plants. Science 148: 339-346.

Sellin A. and Kupper P., 2007. Effects of enhanced hydraulic supply for foliage on stomatal responses in little-leaf linden (Tilia cordata Mill.). Eur. J. For. Res. 126: 241-251.

Sperry J.S., 2000. Hydraulic constraints on plant gas exchange. Agric. For. Meteorol. 104: 13-23.

Sperry J.S., Hacke U.G., Oren R., and Comstock J.P., 2002. Water deficits and hydraulic limits to leaf water supply. Plant Cell Environ. 25: 251-263.

Stöhr A. and Lösch R., 2004. Xylem sap flow and drought stress of Fraxinus excelsior saplings. Tree Physiol. 24: 169-180.

Tognetti R., Johnson J.D., and Michelozzi M., 1995. The response of European beech (Fagus sylvatica L.) seedlings from two Italian populations to drought and recovery. Trees 9: 348-354. 